\title{
胸鎖乳突筋に発生した増殖性筋炎例
}

\author{
谷光 徳晃・久行 敦士・永澤 昌

\section{A Case of Proliferative Myositis Arising in the Sternocleidomastoid Muscle}

\author{
Noriaki Tanimitsu, Atsushi Hisayuki and Akira Nagasawa \\ (Miyoshi General Hospital)
}

\begin{abstract}
We report a rare case of proliferative myositis arising in the sternocleidomastoid muscle. An 80 -yearold man noted a left upper neck swelling on 9 May 2000 and consulted us the same day. A $4 \times 6 \mathrm{~cm}$ smooth, stony hard, and fixed mass was palpable on the left side of the upper neck. CT scans and MRI showed an unclear boundary between the mass and the sternocleidomastoid muscle and a malignant tumor was strongly suspected. An aspiration biopsy was performed on $16 \mathrm{May}$, and the findings suggested that the mass was proliferative myositis or nodular fasciitis. Only oral medication of cefotiam and tranexamic acid was administered for use for 7 days before the diagnosis. After diagnosis, the mass was observed without any medication and it completely disappeared 7 weeks after onset. The clinical course and the pathological features of this case indicated the diagnosis of proliferative myositis. Proliferative myositis is a benign tumorous lesion formed in the striped muscle, and it is important to distinguish it from malignant disease. We considered aspiration biopsy to be very useful in this case.
\end{abstract}

Key words : prolifirative myositis, aspiration biopsy, benign tumorous lesion

はじめに

増殖性筋炎は，表在性の横紋筋内に腫瘤を形成する良 性の線維性増殖で, 頭頸部領域では比較的まれな疾患で ある. その発症は比較的急速で, 腫瘤は進行性に增大す るため, 間葉系悪性腫愓と診断されやすく，その鑑別が 重要である.今回われわれは穿刺吸引細胞診にて診断し 得た胸鎖乳突筋に発生した増殖性筋炎の 1 例を経験し, 本邦にて報告された頭頸部領域の増殖性筋炎について検 討したので，若干の文献的考察を加えて報告する.

\section{症例}

症例 : 80 歳, 男性.

主訴：左頸部腫脹。

既往症 : S 状結腸癌に対し, 平成 12 年 4 月 27 日に当 院外科にて S 状結腸切除術を受けた。
家族歴：特記すべきことなし.

現病歷: 上記術後にて当院外科入院中の平成 12 年 5 月

9 日の朝に, 左頸部腫脹に気付き同日当科受診となった.

初診時, 左胸鎖乳突筋部に一致して, 長径約 $6 \mathrm{~cm}$, 短 径約 $4 \mathrm{~cm}$ の楕円形の表面平滑で石様硬の固定した軽度の 圧痛を伴う腫瘤を触れた（図 1). 発熱はなく, 鼻腔, 咽 喉頭などに異常は認められなかった。

血液検查 : CRP が $0.8 \mathrm{mg} / \mathrm{dl}$ とごく軽度上昇している のみで, 白血球数は $4,400 / \mathrm{mm}^{3}$ と正常であった. ほか の生化学検査, 末梢血検査は正常範囲内であった. 各種 特殊感染症（サイトメガロウイルス, EBウイルス, ヒト $\mathrm{T}$ 細胞白血病ウイルス, クラミジア, トキソプラズマ, および梅毒）の抗体価および膠原病検查（抗核抗体，抗 DNA 抗体, 抗 Sm 抗体, および抗ミトコンドリア抗体）も 正常範囲, $\mathrm{S}$ 状結腸癌に対する手術後であるため腫瘍 


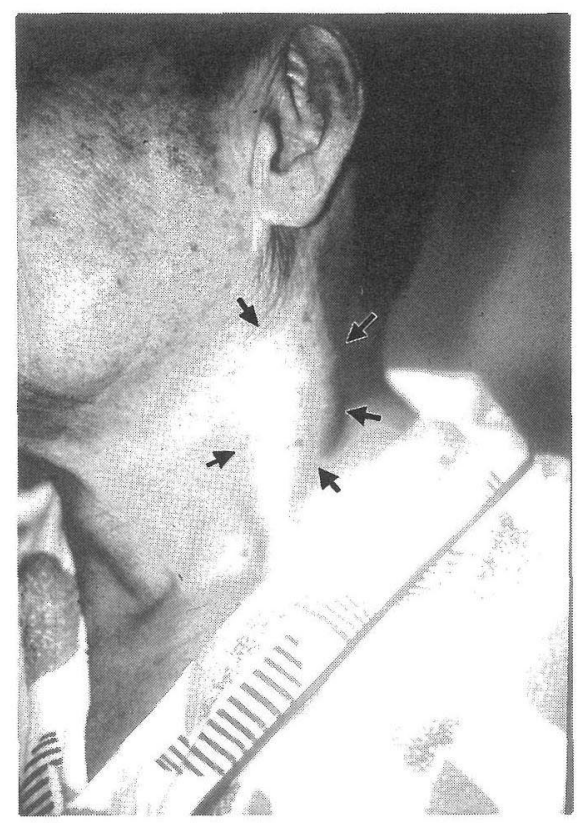

図 1 局所所見

左胸鎖乳突筋部に楕円形の腫瘤 $(6 \times 4 \mathrm{~cm}$ ，表面平滑，石 樣硬）を認める (矢印)。

マーカーCEA を測定したが正常範囲であった。

われわれは側頸囊胞，筋炎，膿瘍を想定し，セフォチ アムおよびトラネキサム酸の経口投与を開始すると同時 に腫瘍性病変も念頭に入れて精査を開始した。

画像検查：5月 16 日撮影の頸部 CT では左胸鎖乳突筋 内に長径 $5 \mathrm{~cm}$ 以上にわたり今回の病変部に一致すると思 われる境界不明瞭，内部不均一で辺縁のみ造影される低 信号領域を認めた（図 2)。リンパ節腫脹その他の病変は 認められなかった。同病変部は MRI でみると，T1 強調 画像においては低信号を示し（図 $3 a$ ），ガドリニウムに より辺縁部中心に不均一に造影された（図 3 b)。T2 強調 画像では辺縁部のリング状の高信号領域に囲まれた低信 号領域として描出された（図 $3 \mathrm{c}$ )。ガリウムシンチグラ フィーでは異常集積を認めなかった。

以上より, 筋肉内の炎症性病変, 出血, 膿瘍などを疑っ たが，触診上非常に硬か⿰七たと，血液検查にて炎症反 応がごくわずかであったことより，腫瘍性病変も否定で きないと判断し,同年 5 月 16 日に穿刺吸引細胞診を施行 した.

穿刺吸引細胞診所見：ギムザ染色では，薄い線維とリ ンパ球がまとわりついた筋細胞が散見され（図 $4 \mathrm{a}$ )，こ れらとともに紡錘形や星紡状の線維芽細胞と思われる細

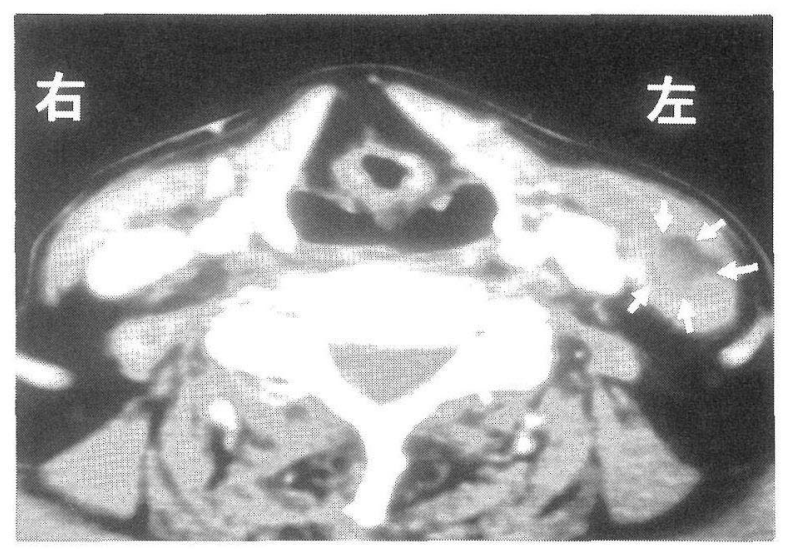

図 2 造影 CT 所見

左胸鎖乳突筋内に境界不明膫，内部不均一で辺縁のみ造 影される低信号領域（矢印）を認めた。

胞が孤立散在性に認められた（図 4 b)。この細胞は形や 大きさが多彩で，またパパニコロウ染色にてクロマチン 增量が軽微な（図4c）ため悪性とは考えにくく，増殖性 筋炎または結節性筋膜炎が考えられるとの報告を得た。

以上の細胞診結果と画像上筋肉内に病変の主体がある ことより，われわれは増殖性筋炎と診断した。診断した 5月 17 日以降セフォチアムおよびトラネキサム酸経口投 与を中止し，経過観察のみとした。腫瘤は 5 月末より縮 小し始め 6 月末には完全に消失した。その後現在まで約 15カ月間，腫瘤の再発は認めていない。

\section{考 察}

増殖性筋炎は，比較的急速に表在性の横紋筋組織内に 腫瘤を形成する良性の増殖性疾患で，臨床的に間葉系悪 性腫瘍と紛らわしく，その鑑別が重要である。本疾患は， 病理組織学的には膠原線維を伴う異型性・多型性の著し い線維芽細胞様細胞の増殖, 神経節細胞様巨細胞の存在, 筋細胞の変性およびリンパ球の浸潤を特徵とする1)2). 1960年にKern ${ }^{3)}$ が外傷により発症する偽肉腫性疾患とし て最初に報告し，1967 年に Enzinger ら ${ }^{4)}$ が本疾患 33 例 を集計して独立した疾患としての概念を確立した。

過去の文献より本疾患の臨床統計を検討する。 Enzingerら ${ }^{4)}$ にれば, 年齢は22〜82歳にわたり 45歳以上 に多く，男女比 4：3 で好発部位は肩甲部や上肢であり， 頭頸部領域においては胸鎖乳突筋，僧帽筋に多いとなっ ている。国内では三国ら5)が 22 例をまとめており，それ によれば平均年齢は 53.7 歳，性は男性 10 例，女性 12 

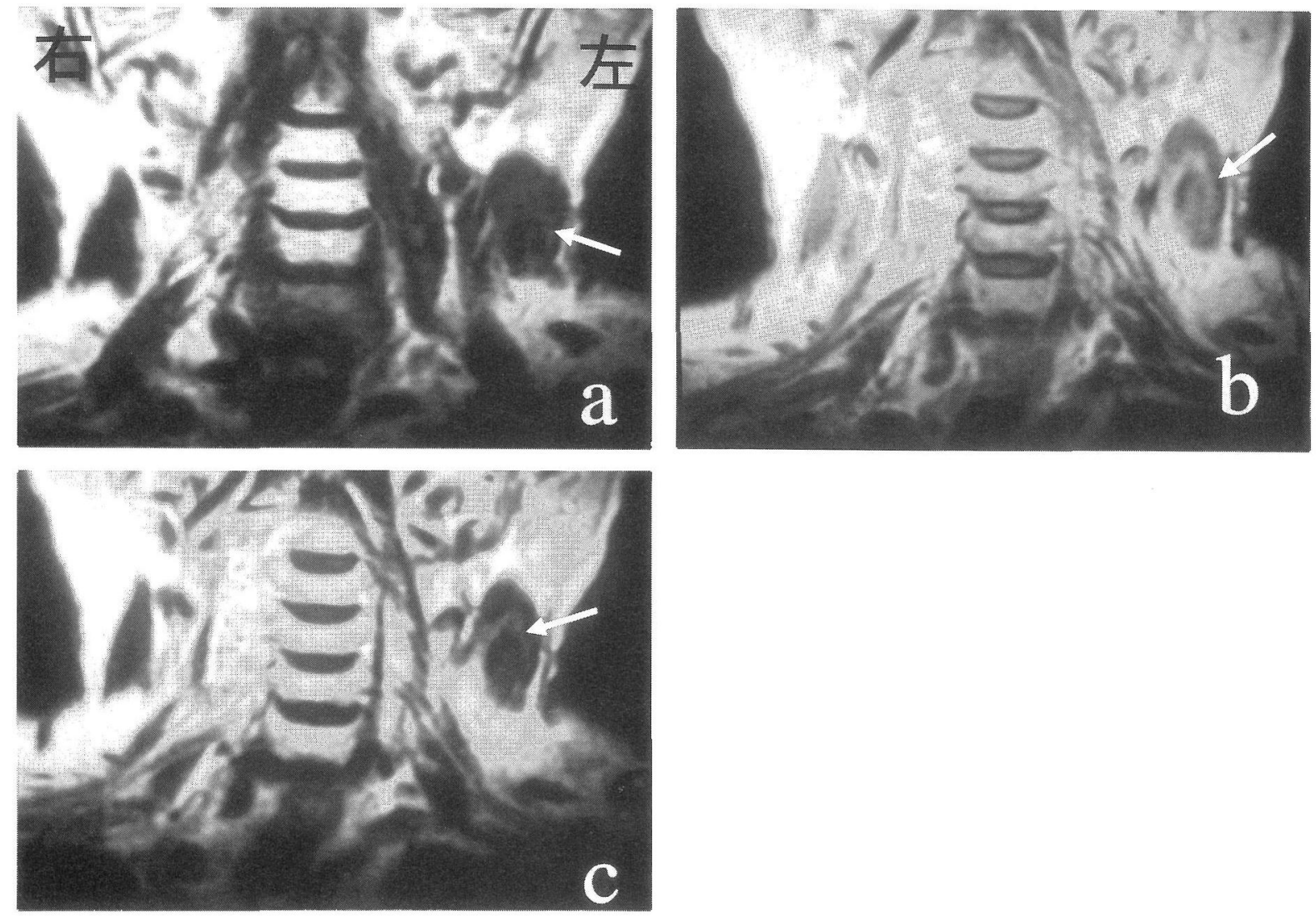

図 3 MRI 所見（前額断. a : T1 強調画像， b : ガドリニウム造影, c : T2 強調画像)

$\mathrm{T} 1$ 強調画像で低信号（a)，ガドリニウムにより辺縁部中心に不均一に造影され（b)，T2 強調画像で辺縁部のリング状の 高信号領域に囲まれた低信号領域（矢印）として描出された（c).

例，発生部位は胸鎖乳突筋が 8 例，大腿 6 例，咬筋 2 例， 前腕，大胸筋，下腿，広背筋，肩甲部，不明がそれぞれ 1 例ずつであった。 以上を総括すると，本疾患は国内外 を問わず 45 歳以上の成人に多く, 性差はほとんぞ認めな い。好発部位は，大腿部，上腕，頸部，躯幹などの横紋 筋である。今回われわれは，本症例を含め国内で報告さ れた頭頸部領域の增殖性筋炎 18 例のうち, 後に本疾患で はないと判明した 1 例を除いた 17 例の臨床統計の検討を 行ったが，ここでは年齢は $18 \sim 80$ 歳の平均 51.5 歳で, 男性 8 例，女性 9 例と性差を認めず，発生部位も胸鎖乳 突筋が 12 例 $(71 \%)$ と大部分を占め（内側翼突筋 2 例, 㚘筋 2 例，咬筋 1 例)，過去の報告と矛盾のない傾向を示 した.

症状は数日から数週間の間に急速に増大する2) 腫瘤で あり，自発痛，圧痛は少ない4)。その腫瘤は境界不明膫 で固さは石様硬6)，大きさは $1 \sim 8 \mathrm{~cm}^{2)}$ とさまざまであ
る.先に述べた国内の頭頸部領域の增殖性筋炎 17 例のう ち, 文献または調查により詳細を知り得た 11 例の臨床所 見を表 1 に示した。これらの大きさは，不明のもの 2 例 を除くと長径 $1.5 \sim 10 \mathrm{~cm}$ で, 自発痛, 圧痛については 全く認めないむのから激しいものまでさまざまであっ た。ちなみに炎症所見（白血球数上昇， CRP 值上昇をた は赤沈充進）については陽性が 7 例，陰性が 2 例，不明 2 例であった。 CT, MRI，エコーなどの画像所見は症例 によってまちまちで特徴的な所見はなかった。この理由 としては, 細胞浸潤の優位な時期, 線維成分の優位な時 期というような炎症の段階や出血の状態によって左右さ れるためと思われる。これらの臨床所見は，本疾患の診 断においては有力な手がかりにはなり得ないと考えられ る.

発生原因については, Kern ${ }^{3)} や$ Chung ら ${ }^{7)}$ は, 局所的 な外傷を挙げ, 紫垣ら ${ }^{8)}$ は, 好発部位が比較的外的刺激 

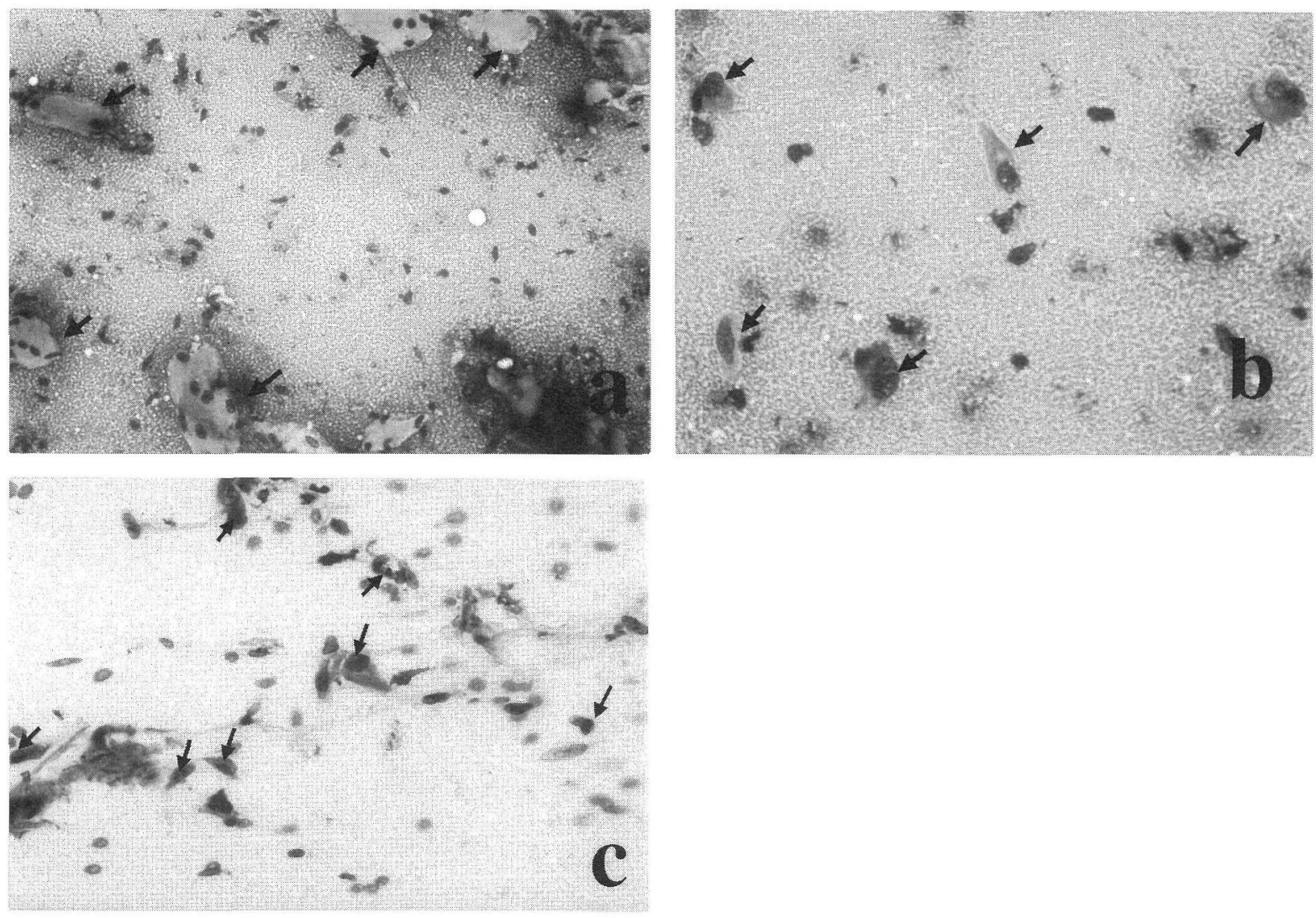

図 4 穿刺吸引細胞診所見 $(\mathrm{a}$ ：ギムザ染色 $\times 100, \mathrm{~b}$ : ギムザ染色 $\times 400, \mathrm{c}$ ：パパニコロウ染色 $\times 400)$

ギムザ染色では薄い線維とリンパ球がをとわりついた筋細胞（a，矢印）が散見され，紡鍾形や星紡状の線維芽細胞様の 細胞（b，矢印）が孤立散在性に認められた。この線維芽細胞様細胞はパパニコロウ染色においてクロマチン増量が軽微 であった ( $c$ ，矢印)。

表 1 国内の頭頸部領域の増殖性筋炎 11 例

\begin{tabular}{|c|c|c|c|c|c|c|c|c|c|}
\hline & 性・年齢 & 発生部位 & 大きさ & $\begin{array}{c}\text { 圧痛または } \\
\text { 自㾞 }\end{array}$ & 炎症所見 & 誘因 & 診断法 & 治療 & 予後 \\
\hline 症例 1 & $57 \cdot$ 女 & 胸鎖乳突筋 & $2 \times 2 \mathrm{~cm}$ & - & - & なし & 摘出生検 & 手術 & 再発なし \\
\hline 2 & $62 \cdot$ 女 & 胸鎖乳突筋 & $4 \times 3 \mathrm{~cm}$ & - & 不明 & 外傷 & 摘出生検 & 手術 & 再発なし \\
\hline 3 & 40 - 男 & 胸鎖乳突筋 & $3 \times 3 \mathrm{~cm}$ & - & 不明 & なし & 摘出生検 & 手術 & 再発なし \\
\hline 4 & $61 \cdot$ 女 & 胸鎖乳突筋 & $6 \times 6 \mathrm{~cm}$ & + & + & なし & 摘出生検 & 手術 & 再発なし \\
\hline 5 & 18 -女 & 煩筋 & $1.5 \times 1 \mathrm{~cm}$ & - & - & なし & 摘出生検 & 手術 & 再発なし \\
\hline 6 & 35 - 女 & 胸鎖乳突筋 & 不明 & - & + & なし & 切開生検 & 経過観察のみ & 治癒 \\
\hline 7 & 33 - 男 & 内側翼突筋 & 不明 & + & + & なし & 臨床所見 & ステロイド & 治癒 \\
\hline 8 & 49 - 男 & 咬筋 & $4 \times 4 \mathrm{~cm}$ & + & + & なし & 穿刺吸引細胞診 & 抗生剂＋ NSAID & 治癒 \\
\hline 9 & 58 - 男 & 胸鎖乳突筋 & $6 \times 5 \mathrm{~cm}$ & + & + & 過運動 & 切開生検 & NSAID & 治癒 \\
\hline 10 & $64 \cdot$-女 & 胸鎖乳突筋 & $10 \times 5 \mathrm{~cm}$ & +++ & + & なし & 切開生検 & 抗生剤＋ステロイド & 治癒 \\
\hline 11 & 80 - 男 & 胸鎖乳突筋 & $6 \times 4 \mathrm{~cm}$ & - & + & なし & 穿刺吸引細胞診 & 抗生剤＋NSAID & 治癒 \\
\hline
\end{tabular}


表 2 軟部組織における偽肉腫性増殖性病変

(紫垣直孝, 他：臨皮 $45 ： 655$ ６59，19918）をもとに作成)

\begin{tabular}{|c|c|c|c|}
\hline & 結節性筋膜炎 & 増殖性筋膜炎 & 増殖性筋炎 \\
\hline $\begin{array}{l}\text { 1. 臨床的 } \\
\text { ·好発年齢 } \\
\text { ·境界 }\end{array}$ & $\begin{array}{l}\text { 特になし } \\
\text { 比較的明瞭 }\end{array}$ & $\begin{array}{c}45 \text { 歳以上 } \\
\text { 不明瞭 }\end{array}$ & $\begin{array}{l}\text { 同左 } \\
\text { 同左 }\end{array}$ \\
\hline $\begin{array}{l}\text { 2. 組織学的 } \\
\text { ·病変部 } \\
\text { ·増殖細胞 } \\
\text { a）線維芽細胞様細胞 } \\
\text { b) 巨大細胞 }\end{array}$ & $\begin{array}{c}\text { 筋膜（真皮下層） } \\
+ \\
+ \\
\text { 組織球様 }\end{array}$ & $\begin{array}{c}\text { 筋膜 } \\
+ \\
+ \\
+ \\
\text { 神経節細胞様 }\end{array}$ & $\begin{array}{c}\text { 筋周膜, 筋内膜 } \\
+ \\
+ \\
\text { 同左 }\end{array}$ \\
\hline
\end{tabular}

を受けやすい部位であり, 組織学的に創傷治癒の過程に 類似していることから，機械的刺激を重要な因子として 挙げている. その一方で三国ら5) や墨ら9) は, 国内の症 例では外傷の既往のある症例はごく一部のみで, 発生原 因は不明と述べている. 検討した 11 例のなかでは, 外傷 の既往があるもの 1 例, 発症前に過運動をしたもの 1 例, 誘因のはっきりしなかったもの 9 例であった. 今回のわ れわれの症例では外傷, 外的刺激などの既往は認めな かった。

本疾患の類縁疾患としては, 結節性筋膜炎（nodular fasciitis)，増殖性筋膜炎（proliferative fasciitis）が挙げら れ，Dahl ら ${ }^{10)}$ は，これら 3 疾患ををとめて “軟部組織に おける偽肉腫性増殖性疾患”と命名することを提唱した。 紫垣ら ${ }^{8)}$ は, 3 疾患とも何らかの刺激により生じる線維 芽細胞性の良性反応性増殖として，同一スペクトラム上 に存在するものとしてとらえた方がよいと述べ，それぞ れの特徴を表 2 のようにまとめている. 今回の症例では, 穿刺吸引細胞診にて特徴的な巨大細胞を認めず, 「増殖性 筋炎または結節性筋膜炎」との報告を得たが, 画像上病 変の主座が筋肉内にあったことと, 境界が不明膫であっ たことより，增殖性筋炎と診断した。

本疾患の鑑別診断で最も重要な疾患は，間葉系悪性腫 瘍, 特に線維性細胞の悪性線維性組織球腫, 隆起性皮膚 線維肉腫, 紡鍾形細胞の平滑筋肉腫, 神経鞘腫である. これらとの鑑別を含めた確定診断には，生検が必須であ るといら意見がほとんどで, 穿刺吸引細胞診のみで診断 できた症例は，本症例を除けば猟捕したなかでは 2 例の み11112) であった。免疫組織化学的検查が上記の間葉系悪 性腫啺の除外の一助になり得るという報告1213) が最近み られるが，はっきりとは確立されていない。
治療であるが，本疾患は治療の必要はなく，痛みの強 い場合は消炎鎮痛剤ないし副腎皮質ステロイドの投与が 行われる，いずれにせよ外科的処置は不要である ${ }^{911114) .}$ しかし，診断のつかないまま外科的処置が行われ，その 後の病理組織検査により初めて診断される症例む多く, 切開生検のみでは不十分で，摘出術にならざるを得ない という意見もある6). 先述の 11 例（表 1）の診断, 治療, 経過をみると，手術施行例は 5 例でこれらはすべて術前 には診断がついて打らず，手術後の病理検查により，初 めて診断された． 5 例とも腫瘤に若干の正常組織をつけ て摘出する術式であった，手術を施行しなかった 6 例の うち，3 例は切開生検にて，2 例は穿刺吸引細胞診にて, 残り 1 例は臨床所見のみから診断された。 これら，手術 を施行しなかった 6 例の治療の内容としては副腎皮質ス テロイド，非ステロイド性消炎鎮痛剤，抗生剤のいずれ かの単独投与，またはこれらを組み合わせた投与が行わ れていた。 治療を行わず経過観察のみ行った症例は 1 例 であった，治療別の経過を検討してみると，手術施行群 は全例再発を認めなかった. 保存的治療群については全 例治瘉しているが，これらが縮小傾向を示し始めたのは 発症後平均 3.5 週で, 消失したのは発症後平均 6 週であっ た.

表 3 穿刺吸引細胞診におおる 增殖性筋炎の細胞構成

・線維芽細胞様紡錘形細胞

・神経節細胞様巨細胞

- 再生筋細胞

- 炎症性細胞

- 膠原線維 


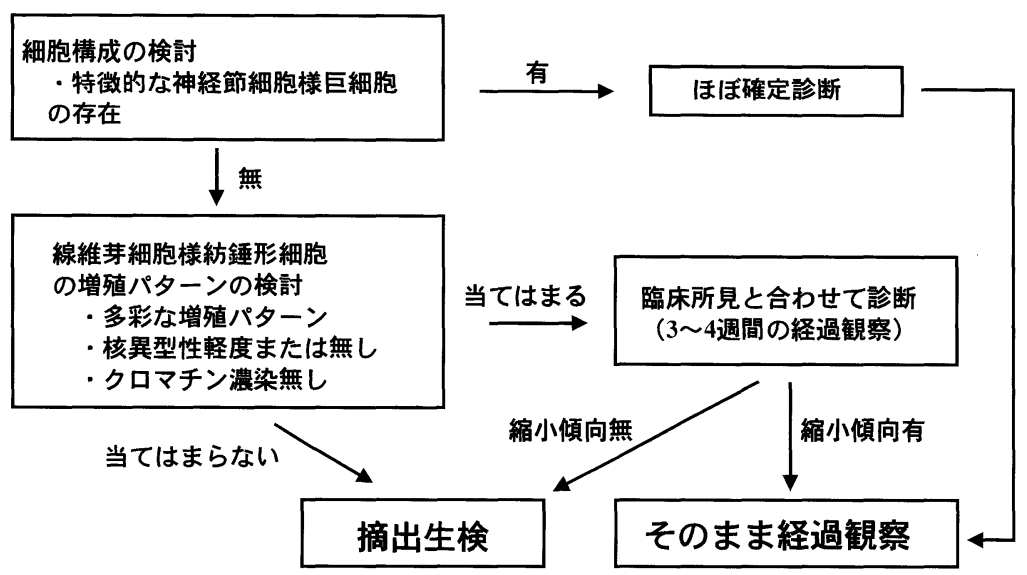

図 5 細胞診による増殖性筋炎の診断の流れ

われわれは今回の症例を穿刺吸引細胞診のみで診断し 得たが，一般的な增殖性筋炎の穿刺吸引細胞診の所見は 増殖の主体である線維芽細胞様細胞, 本疾患に特徵的な 神経節細胞由来の巨細胞をはじめとし, 再生筋細胞, リ ンパ球主体の炎症性細胞，膠原線維がみられる（表 3) 2)12213). 垣花ら ${ }^{13)}$ によれば, 穿刺吸引細胞診において線維 芽細胞様細胞に伴い，本疾患に特徴的な神経節細胞様巨 細胞を認めれば，増殖性筋炎と診断できるが，今回の症 例のように巨細胞が認められない場合でも，増殖する線 維芽細胞様細胞の核の異型性が軽度またはみられないこ と，およびクロマチンの濃染がみられないことより，覀 性腫瘍ではないと判断した上で, 臨床所見, 経過と考え 合わせて本疾患と診断することができる. しかし，穿刺 吸引細胞診で観察された細胞は腫瘤のごく一部であるこ とを念頭に入れて, 厳重に経過観察する必要がある. 先 に述べたように, 今回検討した 11 症例中の保存的治療群 は，約 $3 \sim 4$ 週間で縮小し始めていることから，この期 間を過ぎても縮小傾向を示さない場合は，生検を兼ねた 外科的治療を考慮せねばならず，このような場合に備え た準備，家族への説明が必要と思われる（図 5).

\section{まとめ}

1. 穿刺吸引細胞診にて診断し得た胸鎖乳突筋に発症 した増殖性筋炎の 1 例を経験したので自験例を含めた本 邦報告例のうち詳細を知り得た 11 例について検討した。

2. 間葉系悪性腫場との鑑別が重要な増殖性筋炎の診 断には穿刺吸引細胞診が有用であると思われた.ただし， 腫瘤のごく一部しか観察できないという限界があるため
厳重に経過観察を行う必要があり, $3 \sim 4$ 週間経過して も縮小しない場合は生検を兼ねた外科的治療を行う必要 があると考えた。

\section{参考文献}

1）小林省二, 大森正樹, 大月出祐治 : 間葉系墨性腫瘍とまぎ らわしい増殖性筋炎 (proliferative myositis)。癌の臨床 27 : $1243 \sim 1246,1981$.

2）藤原正之, 飯塚好伯, 山田佐和子, 他：増殖性筋炎の 2 例. J Jpn Soc Clin Cytol $30: 100 \sim 107,1991$.

3) Kern WH : Proliferative myositis, a pseudosarcomatous reaction to injury; report of seven cases. Arch Pathol Lab Med 69: $209 \sim 216,1960$.

4) Enzinger FM and Dulcey F : Proliferative myositis; report of thrty-three cases. Cancer $20: 2213 \sim 2223,1967$.

5）三国尚志, 飯塚桂司, 川浪 貢, 他 : 胸鎖乳突筋に発症し た増殖性筋炎例.耳鼻臨床 $84: 1593 \sim 1597,1991$.

6）岡 亮, 小川佳伸, 生方雪子, 他：胸鎖乳突筋に発症し た増殖性筋炎の 1 症例. 日生医誌 $19: 201 \sim 203,1991$.

7) Chung EB and Enzinger FM : Proliferative fasciitis. Cancer $36: 1450 \sim 1458,1975$.

8）紫垣直孝, 大竹直人, 窪田泰夫, 他: 増殖性筋炎の 1 例. 臨皮 $45: 655 \sim 659,1991$.

9）墨 一郎, 川端五十鈴, 渡邊一夫, 他 : 両側胸鎖乳突筋に 発症した増殖性筋炎例. 耳鼻臨床 $91: 851 \sim 856,1998$.

10) Dahl I and Angervall L : Pseudosarcomatous proliferative lesions of soft tissue with or without bone formations. Acta Pathol Microbiol Scand [A] $85: 577 \sim 589,1977$.

11）大沼英行, 幸山吉彦, 坂井 昇, 他 : 咬筋に発症した増殖 性筋炎の一症例. 耳鼻 $34: 693 \sim 698,1988$.

12）梶岡みゆき，安原真由美，万代須美，他：増殖性筋炎の一 
例. 日本臨床細胞学会広島県支部会報 $16: 69 \sim 71,1995$.

13）垣花昌彦, 大久保誠, 浦崎政治, 他: 覀性線維性組織球腫 (malignant fibrous-histiocytoma) とその周辺の疾患の穿刺吸 引細胞診上の問題点について. J Jpn Soc Clin Cytol 24:426 $\sim 439,1985$

14) Gokkel JM : Proliferative myositis; a case report with fine structural analysis. Virchows Arch [A] 367:345 352, 1975.
原稿受付：平成13年 9 月 21 日

原稿採択：平成13年10月31日

別刷請求先 : 谷光徳晃

T728-8502 三次市東酒屋町字敦盛531

公立三次中央病院耳鼻咽喉科 